\title{
Prognosis when using extracorporeal membrane oxygenation (ECMO) for critically ill COVID-19 patients in China: a retrospective case series
}

\author{
Yingchun Zeng ${ }^{1+} \mathbb{D}$, Zhongxiang Cai ${ }^{2+}$, Yunyan Xianyu ${ }^{2+}$, Bing Xiang Yang ${ }^{3 *}$, Ting Song ${ }^{1 *}$ and Qiaoyuan Yan ${ }^{{ }^{*}}$
}

The World Health Organization (WHO) has characterized the disease, coronavirus disease 2019 (COVID-19), as a pandemic on March 11, 2020 (www.who.int). As of March 11, the WHO had recorded a total of 118,326 confirmed COVID-19 cases, with 4292 death cases (www.who.int). While the cumulative mortality of COVID-19 is 3.63\%, COVID-19 has resulted in more death cases than SARS and MERS combined [1]. Within China, a total of 80,955 cases are confirmed, with 4257 severe cases in mainland China (www.nhc. gov.cn). In severe cases of COVID-19, patients experience rapid disease progression and can quickly progress to acute respiratory distress syndrome (ARDS) [2].

Based on this, when COVD-19 patients develop ARDS and mechanical ventilation cannot be improved, extracorporeal membrane oxygenation (ECMO) can be used [3]. As mortality rates among critically ill COVID-19 patients can be as high as 61.5\% [4], ECMO may play a role in reducing mortality rates [5]. The indications of using ECMO are "For patients with severe ARDS, it is recommended to perform lung expansion. In the case of adequate human resources, prone positioning should be recommended for at least 12 hours per day for

\footnotetext{
*Correspondence: yangbingxiang@163.com; song.ting@163.com; yanqiaoyuan@163.com

†Yingchun Zeng, Zhongxiang Cai and Yunyan Xianyu contributed equally to this work.

${ }^{3}$ School of Health Sciences, Wuhan University, Wuhan, Hubei Province, China 'The Third Affiliated Hospital of Guangzhou Medical University, Guangzhou, China

${ }^{4}$ Union Hospital, Tongji Medical College, Huazhong University of Science and Technology, Wuhan, Hubei Province, China

Full list of author information is available at the end of the article
}

protective ventilation. If severe respiratory failure persisted, then ECMO should be started as soon as possible." [6]

Worldwide data on prognosis when using ECMO to treat critically ill patients with COVID-19 infection are not available, and whether ECMO plays a role in reducing patient mortality rates is currently unknown. This research letter provides the first evidence of prognosis in treating critically ill COVID-19 patients with ECMO in China. These preliminary data were collected from two medical centers of Wuhan, China (Table 1). These data could be of considerable value in judging whether ECMO should be recommended as a salvage therapy for critically ill COVID-19 patients.

To date, the role of ECMO in the management of COVID-19 is unpromising. Nearly half of the patients treated with ECMO died from septic shock and multiple organ failure. The observed late complications included bleeding and infection. While the World Health Organization (WHO) interim guidelines and China's national interim guidelines for the diagnosis and treatment of COVID-19 infection (sixth version) have made general recommendations for the use of ECMO for ARDS and critical COVID-19 infection [3,5], the preliminary evidence available in mainland China does not support this general recommendation.

Certainly, understanding the risk-to-benefit ratio of performing ECMO on critically ill COVID-19 patients is dynamic as the course of this novel disease unfolds. The Chinese government covers all costs to treat patients with the COVID-19 infection, so the cost analysis of ECMO is to date unavailable in mainland China. 
Table 1 Clinical characteristics and ECMO outcomes for critically ill COVID-19 patients $(N=12)$

\begin{tabular}{|c|c|c|c|c|}
\hline Variables & Mean (SD) & Range & $n$ & $\%$ \\
\hline Age (years) & $50.9(13.5)$ & $35-76$ & & \\
\hline Gender (male) & & & 11 & 91.7 \\
\hline \multicolumn{5}{|l|}{ Comorbidities } \\
\hline Hypertension & & & 1 & 8.3 \\
\hline Heart disease & & & 1 & 8.3 \\
\hline Diabetes & & & 1 & 8.3 \\
\hline Hyperthyroidism & & & 1 & 8.3 \\
\hline \multicolumn{5}{|l|}{ Key reason for ICU admittance } \\
\hline Dyspnea & & & 11 & 91.7 \\
\hline Fever & & & 10 & 83.3 \\
\hline Coma & & & 1 & 8.3 \\
\hline \multicolumn{5}{|l|}{ Treatment type } \\
\hline ECMO & & & 12 & 100 \\
\hline Mechanical ventilation & & & 12 & 100 \\
\hline Antibiotic treatment & & & 12 & 100 \\
\hline Antiviral therapy & & & 12 & 100 \\
\hline Glucocorticoid therapy & & & 10 & 83.3 \\
\hline Supportive therapy based on symptoms & & & 12 & 100 \\
\hline Duration of ECMO use (days) & $11.3(7.8)$ & $3-28$ & & \\
\hline \multicolumn{5}{|l|}{ ECMO prognosis } \\
\hline Improving without ECMO & & & 3 & 25.0 \\
\hline Still alive with ECMO but two with coma & & & 4 & 33.3 \\
\hline Dying & & & 5 & 41.7 \\
\hline
\end{tabular}

Abbreviations: ECMO extracorporeal membrane oxygenation, ICU intensive care unit

However, an average ECMO procedure in the USA costs $\$ 73,122$ USD, indicating that ECMO is a highly resource-demanding procedure [7]. Therefore, a further, larger sample size study and a comprehensive analysis of the medical value of using ECMO on COVID-19 patients are urgently required. Based on the two cohort case series in this study, nearly half of the critically ill COVID-19 patients with ECMO were dying from septic shock and multiple organ failure. As anticipated by MacLaren et al. [3], COVID-19 is a pandemic; all healthcare resources are stretched so that ECMO is not a therapy to be rushed to the frontline. Therefore, interim treatment guidelines [5, 6] of recommending ECMO for critically ill COVID-19 patients should be taken cautiously.

\section{Abbreviations}

ARDS: Acute respiratory distress syndrome; COVID-19: Coronavirus disease detected in 2019; ECMO: Extracorporeal membrane oxygenation
Authors' contributions

YZ, manuscript writing; ZC, YXY, BXY, data collection and analysis; TS, QYY, manuscript revision. The authors read and approved the final manuscript.

\section{Funding}

None.

\section{Availability of data and materials}

The datasets used in the present study are available from the first author and corresponding authors on reasonable request.

\section{Ethics approval and consent to participate}

This study was approved by the institutional review board of Wuhan University School of Health Sciences. Informed consent was waived, as this study was conducted during a public health outbreak.

\section{Consent for publication}

Not applicable.

\section{Competing interests}

None

\section{Author details}

${ }^{1}$ The Third Affiliated Hospital of Guangzhou Medical University, Guangzhou, China. ${ }^{2}$ Renmin Hospital of Wuhan University, Wuhan, Hubei Province, China. ${ }^{3}$ School of Health Sciences, Wuhan University, Wuhan, Hubei Province, China. ${ }^{4}$ Union Hospital, Tongji Medical College, Huazhong University of Science and Technology, Wuhan, Hubei Province, China. 
Received: 9 March 2020 Accepted: 19 March 2020

Published online: 15 April 2020

\section{References}

1. Mahase E. Coronavirus: covid-19 has killed more people than SARS and MERS combined, despite lower case fatality rate. BMJ. 2020;368:m641. https://doi.org/10.1136/bmj.m641.

2. Jiang $C$, Yang F, Zou H, et al. Chinese expert consensus on supportive treatment of extracorporeal membrane oxygenation novel coronavirus pneumonia. Chin J Emerg Med. 2020;29(00):E009. https://doi.org/10.3760/ cma.jissn.1671-0282.2020.0009 [in Chinese].

3. MacLaren G, Fisher D, Brodie D. Preparing for the most critically ill patients with COVID-19: the potential role of extracorporeal membrane oxygenation. JAMA Published online February 19, 2020. doi:https://doi.org/10.1001/jama. 2020.2342.

4. Yang X, Yu Y, Xu J, et al. (2020). Clinical course and outcomes of critically ill patients with SARS-CoV-2 pneumonia in Wuhan, China: a single-centered, retrospective, observational study. Lancet Respir Med. Published online February 21, 2020. doi: https://doi.org/10.1016/\$2213-2600(20)30079-5.

5. Liew MF, Siow WT, MacLaren G, et al. Preparing for COVID-19: early experience from an intensive care unit in Singapore. Crit Care. 2020;24:83. https://doi.org/10.1186/s13054-020-2814-x.

6. Diagnosis and treatment guideline for COVID-19 infection (trial version 6) http://www.nhc.gov.cn, Accessed 18 Feb 2020. [in Chinese].

7. Mishra V, Svennevig JL, Bugge JF, et al. Cost of extracorporeal membrane oxygenation: evidence from the Rikshospitalet University Hospital, Oslo, Norway. Eur J Cardiothorac Surg. 2010;37(2):339-42. https://doi.org/10.1016/ j.ejcts.2009.06.059.

\section{Publisher's Note}

Springer Nature remains neutral with regard to jurisdictional claims in published maps and institutional affiliations.

Ready to submit your research? Choose BMC and benefit from:

- fast, convenient online submission

- thorough peer review by experienced researchers in your field

- rapid publication on acceptance

- support for research data, including large and complex data types

- gold Open Access which fosters wider collaboration and increased citations

- maximum visibility for your research: over $100 \mathrm{M}$ website views per year

At $\mathrm{BMC}$, research is always in progress.

Learn more biomedcentral.com/submissions 